\title{
当教室における舌癌の治療と予後の検討
}

斉藤進・玉井達人・北川徹・古賀一郎

増田元三郎・関戸幹夫・鈴木和彦・河内四 郎

藤田浄秀・増田正樹・大谷隆俊

\section{Estimation of therapeutic method and prognosis of carcinoma of the tongue}

\author{
Susumu SaItoh - Tatsundo TamaI - Toru Kitagawa - Ichiro KogA \\ Genzaburo Masuda - Mikio SeKmo - Kazuhiko Suzuki - Shiro KawachI \\ Kiyohide FujrTA = Masaki Masuda $\cdot$ Takatoshi OhtanI
}

緒

\section{言}

われわれは䅡口腔領域悪性腫瘍のうち舌癌の治療と予 後を検討する目的で, 昭和 42 年 1 月から昭和 55 年 4 月ま での約 13 年間に，横浜市立大学 医学部口腔外科を受診 し，治療を施行した 1 次症例58名に対し統計的観察を行 ったので報告する.

\section{対象症例の臨床統計的観察}

昭和 42 年 1 月 1 日から昭和 55 年 4 月 30 日までに, 本学 医学部口腔外科を受診した舌癌を対象とした。これらの 症例はすべて昭和 56 年 4 月 30 日まで, 最低 1 年から最高 14年間，経過を観察し得た 1 次症例である。なお，舌根 部癌は UICC の分類で中咽頭（口部咽頭）に含まれて いるが，臨床的に区別が困難な症例も多く，一括して舌 癌に含めた。

1. 性別および年齢別頻度（表 1)

性別では男性 37 例 (63.8\%)，女性21例 (36.2\%) で, 男女比は約 $1.8: 1$ であった。

年龄別では 40 歳台が17例 $(29.3 \%)$ で最も多く, 以下 50 歳台 13 例 $(22.4 \%), 70$ 歳台 12 例 $(20.7 \%), 60$ 歳台 10 例 $(17.2 \%)$ の順であった。 また最低年龄は25歳，最高 年龄84歳であった．平均年齢は55.7歳で，男性53.6歳， 女性59.4歳で, 女性の方が高齢者が多かった。

橫浜市立大学医学部口腔外科学教室（主任：大谷隆 俊教授)

Department of Oral Surgery, School of Medicine, Yokohama City University (Chief: Prof. Takatoshi Ohtani)

受付日：昭和56年 5 月 25 日

\section{2. 発生部位（表 2 ）}

発生部位を表 2 のように，舌縁部，舌下面部，舌根 部, 舌背部に分類した，部位別頻度では，舌縁部が38例 (65.5\%) で最も高く，以下，舌下面部14例 (24.1\%), 舌根部, 舌背部各 3 例 (5.2\%) の順であった。 また左 右差は各部位ともほとんどなかった。

3. 初診時の臨床視診型分類 (表 3)

初診時の腫瘍の肉眼所見として, 潰瘍型, 腫瘤型, 白

表 1 性別と年齢

\begin{tabular}{c|r|r|r}
\hline 年 齢 & 男 & 女 & 計 (\%) \\
\hline $20 \sim 29$ & 2 & 0 & $2(3.4 \%)$ \\
$30 \sim 39$ & 1 & 2 & $3(5.2 \%)$ \\
$40 \sim 49$ & 13 & 4 & $17(29.3 \%)$ \\
$50 \sim 59$ & 9 & 4 & $13(22.4 \%)$ \\
$60 \sim 69$ & 7 & 3 & $10(17.2 \%)$ \\
$70 \sim 79$ & 4 & 8 & $12(20.7 \%)$ \\
$80 \sim 89$ & 1 & 0 & $1(1.7 \%)$ \\
\hline 計 & 37 & 21 & $58(100 \%)$ \\
\hline
\end{tabular}

表 2 発生部位

\begin{tabular}{ccc|c}
\hline & & & 症 例 数 (\%) \\
\hline 舌 & 縁 & 部 & $38(65.5 \%)$ \\
舌 & 下 面 & 部 & $14(24.1 \%)$ \\
舌 & 根 & 部 & $3(5.2 \%)$ \\
舌 & 背 & 部 & $3(5.2 \%)$ \\
\hline & 計 & $58(100 \%)$ \\
\hline
\end{tabular}


表 3 臨床視診型分類

\begin{tabular}{|c|c|c|}
\hline & & 症 例 数 $(\%)$ \\
\hline 箅 & 型 & $23(39.7 \%)$ \\
\hline 瘤 & 型 & $14(24.1 \%)$ \\
\hline 斑 & 型 & $0\left(\begin{array}{ll}0 & \%\end{array}\right)$ \\
\hline 尰 瘤・白 斑 & 型 & $10(17.2 \%)$ \\
\hline 腫 瘤・湿 㿇 开 & 型 & $6(10.3 \%)$ \\
\hline 溃 䂓・白 斑 开 & 型 & $3(5.2 \%)$ \\
\hline 腫瘤・溲㻛・白斑型 & & $2(3.4 \%)$ \\
\hline 計 & & $58(100 \%)$ \\
\hline
\end{tabular}

表 5 病期分類

\begin{tabular}{c|c}
\hline & 症 例 数 (\%) \\
\hline I & $13(22.4 \%)$ \\
II & $12(20.7 \%)$ \\
II & $16(27.6 \%)$ \\
IV & $17(29.3 \%)$ \\
\hline 計 & $58(100 \%)$ \\
\hline
\end{tabular}

斑型およびそれらの混合型に分類した，頻度としては潰 癔型が23例 $(39.7 \%)$ で最も高く，以下腫瘤型14例(24.1 $\%)$, 腫瘤・白斑型 10 例 (17.2\%), 腫瘤・潰瘍型 6 例 $(10.3 \%)$, 潰瘍・白斑型 3 例 $(5.2 \%)$, 腫瘤・潰瘍・白 斑型 2 例 $(3.4 \%)$ の順であった。 また白斑型は 1 例む なかった。

\section{4. 組織型分類}

病理組織学的分類では，扁平上皮癌 57 例 $(98.3 \%)$,

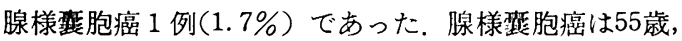
女性の舌下面に発生したもので, 視診型は腫瘤型であっ た.

\section{TNM 分類 (表 4)}

1978年 UICC (Geneva) 提案による TNM 分類1を 使用した， T分類別にみると， T 2 が28例 (48.3\%) で 最も多く，以下 $\mathrm{T} 1$ が18例 $(31.0 \%) ， \mathrm{~T} 3$ が 9 例(15.5 \%), T 4 が 3 例 (5.2\%) の順であった。

$\mathrm{N}$ 分類別にみると, N 0 が 28 例 (48.3\%), 次いでN1 が14例 (24.1\%)，N 2, N 3 が各 8 例 (3.8\%) であっ た. M分類では全例M0であった。

\section{6. 病期分類 (表 5 )}

前述の UICC 分類に基づき病期を I 期から IV 期に分 類した。頻度は $V$ 期が17例（29.3\%）で最も多く，次い でII 期16例 $(27.6 \%)$ ， I 期13例 $(22.4 \%)$ ，II 期12例の 順であった。

\section{7. 治療法分類 (表 6 )}

原発巣あるいは所属リンパ節転移巣に対する初回治療
表 4 TNM 分類

\begin{tabular}{c|c|c|c|c|c}
\hline & $\mathrm{N} 0$ & $\mathrm{~N} 1$ & $\mathrm{~N} 2$ & $\mathrm{~N} 3$ & 計 (\%) \\
\hline $\mathrm{T} 1$ & 13 & 4 & 1 & 0 & $18(31.0 \%)$ \\
$\mathrm{T} 2$ & 12 & 7 & 5 & 4 & $28(48.3 \%)$ \\
$\mathrm{T} 3$ & 2 & 3 & 2 & 2 & $9(15.5 \%)$ \\
$\mathrm{T} 4$ & 1 & 0 & 0 & 2 & $3(5.2 \%)$ \\
\hline (計 & 28 & 14 & 8 & 8 & $58(100 \%)$ \\
$(\%)$ & $(48.3 \%)$ & $(24.1 \%)$ & $(13.8 \%)$ & $(13.8 \%)$ & \\
\hline
\end{tabular}

表 6 治療法分類

\begin{tabular}{|c|c|}
\hline 治 療 法（略記法） & 症例数 \\
\hline 手術単独治療（手） & 2 \\
\hline 放射線単独治療（放） & 19 \\
\hline 化学療法単独治療（動注）（化） & 1 \\
\hline 手術・術後照射（手 $\rightarrow$ 放） & 2 \\
\hline 術前照射 - 手術, 化学療法併用 (放 $\rightarrow$ 手+化) & 2 \\
\hline 手術, 化学療法併用 (手+化) & 8 \\
\hline 放射線，化学療法併用（放+化） & 23 \\
\hline 放射線, 化学療法・頸部遊清（放＋化十手） & 1 \\
\hline 計 & 58 \\
\hline
\end{tabular}

の方法は，表 6 に示す通りである。この中では放射線， 化学療法併用（放+化）が23例で最も多く, 以下，放射 線単独治療 (放) 19例, 手術, 化学療法併用 (手十化) 8 例, 手術単独治療 (手), 手術 - 術後照射 (手 $\rightarrow$ 放), 術前照射 - 手術, 化学療法併用（放一手十化）が各 2 例, 化学療法単独治療 (化), 放射線, 化学療法・頸部 廓清（放+化+手）が各 1 例であった。

手術方法を分類すると, 部分切除 9 例, 部分切除・頸 部遊清術 4 例, 半側切除 1 例であった。

化学療法は全身投与29例，動注 6 例であった．全身投 与群では，BLM を使用した症 例が 半数以上を占めた (表 7 ).

放射線治療をさらに分類すると，外照射と小線源によ る組織内照射を併用した症例が33例で最も多く，次いで 外照射単独 12 例, 小線源による組織内照射単独 2 例であ った（表 8).

\section{治 療 成 績}

\section{1. 臨床視診型と治瘾率（表 9)}

初診時の臨床視診型分類別の治瘾率を調べると, 腫 瘤・白斑型が $90.9 \%$ で最も良く，次いで溃㵿・白斑型 $66.7 \%$, 腫瘤型打よび腫瘤・溃瘍・白斑型 $50.0 \%$, 潰瘍 型 $47.8 \%$ ，腫瘤・潰痬型 $0 \%$ の順であった。

また全症例における治癒率は $53.4 \%$ であった。 
表 7 化学療法分類

\begin{tabular}{|c|c|c|c|}
\hline & 身 投 与 & & 29 \\
\hline & $5-\mathrm{Fu}$ & 8 & \\
\hline & $5-F u+C Q$ & 2 & \\
\hline & $5-\mathrm{Fu}+\mathrm{MMC}$ & 1 & \\
\hline & BLM & 15 & \\
\hline & $\mathrm{BLM}+\mathrm{MMC}$ & 1 & \\
\hline & BLM+CPA & 1 & \\
\hline & NK-631 & 1 & \\
\hline \multirow[t]{6}{*}{ 動 } & 注 & & 6 \\
\hline & $5-\mathrm{Fu}$ & 2 & \\
\hline & $5-F u+C Q$ & 2 & \\
\hline & BLM & 1 & \\
\hline & $\mathrm{BLM}+\mathrm{MMC}$ & 1 & \\
\hline & 計 & & 35 \\
\hline
\end{tabular}

表 9 臨床視診型と治瘾率

\begin{tabular}{|c|c|c|c|c|c|}
\hline & & & & 治 施率 (\%) & 生存者数 \\
\hline 尰 & 瘤・白 & 斑 & 型 & $10 / 11 \quad(90.9 \%)$ & 10 \\
\hline 潰 & 瘍 - 白 & 斑 & 型 & $(66.7 \%)$ & 2 \\
\hline 尰 & 瘤 & & 型 & $7 / 14 *(50.0 \%)$ & 7 \\
\hline \multirow{2}{*}{ 遇 } & 召・潰瘍 & 白玨 & & $1 / 2 \quad(50.0 \%)$ & 1 \\
\hline & 瘍 & & 型 & $11 / 23 *(47.8 \%)$ & 12 \\
\hline 腫 & 瘤・潰 & 瘍 & 型 & $0 / 5 \quad\left(\begin{array}{ll}0 & \%\end{array}\right)$ & 0 \\
\hline \multicolumn{4}{|c|}{ 計 } & $31 / 58 \quad(53.4 \%)$ & 32 \\
\hline
\end{tabular}

*: 他因死各 1 例を含む

\section{2. $\mathbf{T}$ 分類と予後 (表10)}

$\mathrm{T}$ 分類別に期間 1 年, 3 年, 5 年の粗生存率（絶対生 存率)を調べる， T1 症例では，それぞれ100\%，88.2 $\%, 78.6 \%$, であった. T 2 症例では $78.6 \%, 52.4 \%$, $50.0 \%, \mathrm{~T} 3$ 症例 $77.8 \%, 40.0 \%, 25.0 \%$ で, $\mathrm{T} 4$ 症例 はすへて 1 年以内に死亡した。 また全症例に护ける累積 生存率を調べると 1 年 $81.0 \%, 3$ 年 $60.0 \%, 5$ 年 $57.3 \%$ で, 粗生存率との間に著しい差異はなかった。

\section{N分類と予後（表11）}

同棣に $\mathrm{N}$ 分類別の生存率を調べる $\mathrm{N} 0$ 症例では 1 年生存率 $89.3 \%, 3$ 年生存率 $78.3 \%, 5$ 年生存率 $72.2 \%$ であった。 N 1 症例では，それぞれ $85.7 \% ， 50.0 \%$ ， $55.6 \%, \mathrm{~N} 2$ 症例では, $87.5 \%, 80.0 \%, 50.0 \%, \mathrm{~N} 3$

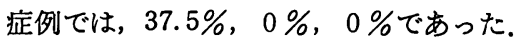

4. 病期分類と予後 (表12)

病期分類別生存率では，I期の 1 年， 3 年はともに $100 \%, 5$ 年は $81.8 \%$ であった。 II 期では，それぞれ $83.3 \%, 55.6 \%, 50.0 \%$, III 期は87.5\%, $53.8 \%, 60.0$ \%，IV期は $58.8 \% ， 33.3 \% ， 14.3 \%$ でった.
表 8 放射線治療分類

\begin{tabular}{|c|c|c|c|}
\hline 外 & 照 射 & & 12 \\
\hline \multicolumn{2}{|c|}{ 外炤射十小線源 } & & 33 \\
\hline \multicolumn{2}{|c|}{ Cs } & 21 & \\
\hline \multicolumn{2}{|r|}{$\mathrm{Rn}$} & 4 & \\
\hline \multicolumn{2}{|r|}{$\mathrm{Au}$} & 3 & \\
\hline \multicolumn{2}{|r|}{$\mathbf{R a}$} & 1 & \\
\hline \multicolumn{2}{|r|}{$\mathrm{Ra}+\mathrm{Cs}$} & 2 & \\
\hline \multicolumn{2}{|r|}{$\mathrm{Cs}+\mathrm{Au}$} & 2 & \\
\hline & 線＼cjkstart源 & & 2 \\
\hline & Cs & 1 & \\
\hline & $\mathbf{R a}$ & 1 & \\
\hline & 計 & & 47 \\
\hline
\end{tabular}

表 $10 \mathrm{~T}$ 分類別粗生存率および累積生存率

\begin{tabular}{|c|c|c|c|}
\hline & 1 年 & 年 & 5 \\
\hline $\mathrm{T} 1$ & $\begin{array}{r}18 / 18 \\
(100 \%)\end{array}$ & $\begin{array}{c}15 / 17 \\
(88.2 \%)\end{array}$ & $\begin{array}{c}11 * / 14 \\
(78.6 \%)\end{array}$ \\
\hline $\mathrm{T} 2$ & $\begin{array}{r}22 / 28 * \\
(78.6 \%)\end{array}$ & $\begin{array}{c}11 / 21 \\
(52.4 \%)\end{array}$ & $\begin{array}{c}7 / 14 \\
(50.0 \%)\end{array}$ \\
\hline T3 & $\begin{array}{c}7 / 9 \\
(77.8 \%)\end{array}$ & $\begin{array}{c}2 / 5 \\
(40.0 \%)\end{array}$ & $\begin{array}{c}1 / 4 \\
(25.0 \%)\end{array}$ \\
\hline $\mathrm{T} 4$ & $\left(0^{0 / 3} \%\right)$ & $\left(0^{0 / 3} \%\right)$ & $\left(0^{0 / 2} \%\right)$ \\
\hline 粗生存率 & $\begin{array}{c}47 / 58 \\
(81.0 \%)\end{array}$ & $\begin{array}{c}28 / 46 \\
(60.9 \%)\end{array}$ & $\begin{array}{c}19 / 34 \\
(55.9 \%)\end{array}$ \\
\hline 累栍生存率 & $81.0 \%$ & $60.0 \%$ & $57.3 \%$ \\
\hline
\end{tabular}

*: 他因死各 1 例を含む

\section{5. 治療法と予後}

a） T分類別治療法と生存年数（表13）

$\mathrm{T} 1$ 症例では手術主体治療（手，手十化，手 $\rightarrow$ 放，放 $\rightarrow$ 手十化) は 7 例中 6 例 (85.7\%) が生存している. 死 亡した 1 例は手術・化学療法併用症例 (手十化) で局所 再発をきたした，放射線主体治療（放，放十化）は11例 に対して行い6 例 (54.5\%) が生存している.

T 2 症例では, 手術主体治療（手, 手十化, 放 $\rightarrow$ 手十 化）は 6 例中 3 例 $(50.0 \%)$ ，放射線主体治療（放，放 十化）は 22 例中 13 例 $(59.1 \%)$ がそれぞれ生存してい る.

T 3 症例では手術主体治療（手+化）は 1 例のみに施 行したが現在生存中である。放射線主体治療（放, 放十 化） は 7 例中 3 例 $(42.9 \%)$ が生存している. 化学療法 単独治療（化）の 1 例は 1 年以内に死亡した.

T 4 症例では手術主体療法を施行したものはなく, 放 射線主体治療（放十化）を 2 例に, 放射線, 化学療法・ 頸部遊清（放十化+手）を1例に対して行ったが，すべ 
表 $11 \mathrm{~N}$ 分類別粗生存率

\begin{tabular}{|c|c|c|c|}
\hline & 年 & 年 & 年 \\
\hline No & $25 / 28(89.3 \%)$ & $18 / 23(78.3 \%)$ & $13 * / 18(72.2 \%)$ \\
\hline $\mathrm{N} 1$ & $12 / 14 *(85.7 \%)$ & $6 / 12(50.0 \%)$ & $5 / 9(55.6 \%)$ \\
\hline N2 & $7 / 8(87.5 \%)$ & $4 / 5(80.0 \%)$ & $1 / 2(50.0 \%)$ \\
\hline N3 & $3 / 8(37.5 \%)$ & $0 / 6\left(\begin{array}{ll}0 & \%\end{array}\right)$ & $0 / 5\left(\begin{array}{ll}0 & \%\end{array}\right)$ \\
\hline & $47 / 58(81.0 \%)$ & $28 / 46(60.9 \%)$ & $19 / 34(55.9 \%)$ \\
\hline
\end{tabular}

*：他因死各 1 例を含む
表 12 病期分類別粗生存动

\begin{tabular}{|c|c|c|c|}
\hline & 年 & 年 & 年 \\
\hline I & $13 / 13(100 \%)$ & $12 / 12(100 \%)$ & $9 * / 11(81.8 \%)$ \\
\hline II & $10 / 12(83.3 \%)$ & $5 / 9(55.6 \%)$ & $3 / 6(50.0 \%)$ \\
\hline III & $14 / 16 *(87.5 \%)$ & $7 / 13(53.8 \%)$ & $6 / 10(60.0 \%)$ \\
\hline IV & $10 / 17(58.8 \%)$ & $4 / 12(33.3 \%)$ & $1 / 7(14.3 \%)$ \\
\hline 計 & $47 / 58(81.0 \%)$ & $28 / 46(60.9 \%)$ & $19 / 34(55.9 \%$ \\
\hline
\end{tabular}

* : 他因死各 1 例を含む

表 $13 \mathrm{~T}$ 分類別治療法と生存年数

\begin{tabular}{|c|c|c|c|c|c|c|c|c|c|c|}
\hline & & 療 法 & $\begin{array}{c}1 \text { 年以内 } \\
\text { 死 }\end{array}$ & 1 年生存 & 2 年生存 & 3 年生存 & 4 年生存 & 5 年生存 & 計 & $\begin{array}{l}\text { 現在生 } \\
\text { 存者数 }\end{array}$ \\
\hline \multirow[t]{2}{*}{$\mathrm{T} 1$} & 手 & $\begin{array}{c}\text { 手 } \\
\text { 手十化 } \\
\text { 手 } \rightarrow \text { 放 } \\
\text { 放 } \rightarrow \text { 手+化 }\end{array}$ & & $2(1)$ & & 1 (1) & $1(1)$ & $\begin{array}{l}1(1) \\
1(1) \\
1(1)\end{array}$ & $\begin{array}{l}1 \\
3 \\
2 \\
1\end{array}$ & $\begin{array}{l}1 \\
2 \\
2 \\
1\end{array}$ \\
\hline & 放 & $\begin{array}{c}\text { 放 } \\
\text { 放+化 }\end{array}$ & & $1(0)$ & & & $\begin{array}{l}1(0) \\
1(0)\end{array}$ & $\begin{array}{l}5 *(4) \\
3(2)\end{array}$ & $\begin{array}{l}6 \\
5\end{array}$ & $\begin{array}{l}4 \\
2\end{array}$ \\
\hline \multirow[t]{2}{*}{$\mathrm{T} 2$} & 手 & $\begin{array}{c}\text { 手 } \\
\text { 手十化 } \\
\text { 放 } \rightarrow \text { 手十化 }\end{array}$ & 2 & $1(0)$ & & $1(1)$ & & $\begin{array}{l}1(1) \\
1(1)\end{array}$ & $\begin{array}{l}1 \\
4 \\
1\end{array}$ & $\begin{array}{l}0 \\
2 \\
1\end{array}$ \\
\hline & 放 & $\begin{array}{c}\text { 放 } \\
\text { 放+化 }\end{array}$ & $\begin{array}{l}2 \\
2^{*}\end{array}$ & $\begin{array}{l}4(2) \\
5(3)\end{array}$ & $1(0)$ & $2(2)$ & $1(1)$ & $\begin{array}{l}4(4) \\
1(1)\end{array}$ & $\begin{array}{l}12 \\
10\end{array}$ & $\begin{array}{l}7 \\
6\end{array}$ \\
\hline \multirow{3}{*}{$\mathrm{T} 3$} & 手 & 手十化 & & 1 (1) & & & & & 1 & 1 \\
\hline & 放 & $\begin{array}{c}\text { 放 } \\
\text { 放十化 }\end{array}$ & 1 & $\begin{array}{l}1(0) \\
3(1)\end{array}$ & & $1(1)$ & & $1(1)$ & $\begin{array}{l}1 \\
6\end{array}$ & $\begin{array}{l}0 \\
3\end{array}$ \\
\hline & 化 & 化 & 1 & & & & & & 1 & 0 \\
\hline \multirow{2}{*}{$\mathrm{T} 4$} & 放 & 放+化 & 2 & & & & & & 2 & 0 \\
\hline & \multicolumn{2}{|c|}{ 放＋化十手 } & 1 & & & & & & 1 & 0 \\
\hline & & & 11 & $18(8)$ & $1(0)$ & $5(5)$ & $4(2)$ & 19 (17) & 58 & 32 \\
\hline
\end{tabular}

（）内は生存者数

*：他因死各 1 例を含む

て 1 年以内に死亡した.

\section{b ）治療法別予後（表14）}

初回治療後の予後を，表14のように5 型に分類した. 局所再発とは, 初回治療によって臨床的あるいは病理組 織学的に治癒した原発栄に再び腫瘍の発現をきたしたも の, 頸部リンパ節転移とはN0 症例に沶いて, 治療後,

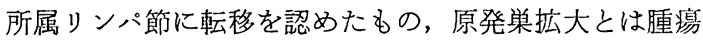
の control ができなかったもの，転移栄拡大とはN 1〜 3 症例に拈いて治療後も拡大傾向を認めたものである.
手術主体治療（手, 手 $\rightarrow$ 放, 放 $\rightarrow$ 手十化) 14例中, 初 回治療にて治癒したものは 9 例（治癒率：64.3\%), 局 所再発は 2 例 (再発率: $14.3 \%$ ), 転移栄抎大は 3 例 (21.4\%) であった。頸部りンパ節への転移は 1 例もな かった（手術主体治療施行例中 No は 5 例).

放射線主体治療（放, 放十化）42例中, 初回治療にて 治癒は 10 例 (治癒率: $23.8 \%$ ), 局所再発は6 例 (再発 率 : $14.3 \%$ ), 頸部リンパ節への転移は 8 例 (転移率 : 23 例中 8 例, $34.8 \%$ ), 原発巣扗大は11例 $(26.2 \%)$, 転移 
表 14 治療法別予後

\begin{tabular}{|c|c|c|c|c|c|c|c|}
\hline 治 & 療 & $\begin{array}{l}\text { 初回治療に } \\
\text { て治瘾 }\end{array}$ & 局 所 再 発 & $\begin{array}{l}\text { 頸部リンハ侱 } \\
\text { 節への転 }\end{array}$ & 原発巣拡大 & 転移巣拡大 & 計 \\
\hline \multirow{4}{*}{ 手 } & 手 & 1 & 1 & 一 & - & - & 2 \\
\hline & 手 $\rightarrow$ 放 & 2 & - & - & - & - & 2 \\
\hline & 故 $\rightarrow$ 手 +化 & 2 & - & 一 & - & - & 2 \\
\hline & 手+化 & 4 & 1 & - & - & 3 & 8 \\
\hline 小 & 計 & $9(64.3 \%)$ & $2(14.3 \%)$ & -* & - & $3(21.4 \%)$ & 14 \\
\hline \multirow{2}{*}{ 放 } & 放 & 5 & 3 & 5 & 3 & 3 & 19 \\
\hline & 放+化 & 5 & 3 & 3 & 8 & 4 & 23 \\
\hline 小 & 計 & $10(23.8 \%)$ & $6(14.3 \%)$ & $8+(19.0 \%)$ & $11(26.2 \%)$ & $7(16.7 \%)$ & 42 \\
\hline \multirow{2}{*}{ その他 } & & - & - & - & 1 & - & 1 \\
\hline & 放十化+手 & - & 一 & - & 1 & - & 1 \\
\hline \multirow[t]{2}{*}{ 小 } & 計 & - & - & - & $2(100 \%)$ & - & 2 \\
\hline & 計 & $19(32.8 \%)$ & $8(13.8 \%)$ & $8(13.8 \%)$ & $13(22.4 \%)$ & $10(17.2 \%)$ & 58 \\
\hline
\end{tabular}

*: 手術主体治療中 N0 5 例

$\dagger$ : 放射線主体治療中 No 23 例

表 15 初回治療による予後と生存年数

\begin{tabular}{|c|c|c|c|c|c|c|c|c|}
\hline & $\begin{array}{l}1 \text { 年以 } \\
\text { 内死亡 }\end{array}$ & 1 年生存 & 2 年生存 & 3 年生存 & 4 年生存 & 5 年生存 & 計 & 現在生存者数 \\
\hline 初回治療にて治撚 & & $4(4)$ & & $3(3)$ & $2(2)$ & $10(10)$ & 19 & $19(100 \%)$ \\
\hline 局所再発 & 1 & $4(1)$ & & & $1(0)$ & $2 *(1)$ & 8 & $2(25.0 \%)$ \\
\hline 钼部リンパ節への転移 & & $4(1)$ & & $1(1)$ & & $3(2)$ & 8 & $4(50.0 \%)$ \\
\hline 原発巣拡大 & 8 & $3(1)$ & $1(0)$ & & $1(0)$ & & 13 & $1(7.7 \%)$ \\
\hline 転移巣払大 & $2 *$ & $3(1)$ & & $1(1)$ & & $4(4)$ & 10 & $6(60.0 \%)$ \\
\hline 計 & 11 & $18(8)$ & $1(0)$ & $5(5)$ & $4(2)$ & $19(17)$ & 58 & $32(55.2 \%)$ \\
\hline
\end{tabular}

*: 他因死各 1 例を含む

（）内は生存者数

单払大は 7 例 $(16.7 \%)$ であった.

化学療法単独治療 (化) および放射線, 化学療法・頸 部廓清（放十化十手）は各 1 例で，いずれも原発巣の抎 大をきたした。

c）初回治療による予後と生存年数（表15）

前述の予後と生存年数を調へたところ，初回治療にて 治瘜した症例は，他因死亡すなく現在まですべて生存し ている. 局所再発症例は 8 例中 2 例 (25.0\%) が生存し ているのみで予後は不良であった。頸部りンパ節への転 移をきたした症例は 8 例中 4 例 $(50.0 \%)$ が生存してい る. 原発巣払大症例は 14 例中 1 例 (7.7\%) が生存して いるたけで， 8 例が 1 年以内に死亡していた。 また生存 中の 1 例もいまだ抎大傾向にある、転移巣払大症例では
10例中 6 例 $(60.0 \%)$ が生存しており，その中の 4 例は 5 年以上生存している。

d）局所再発症例に対する治療と予後（表16）

局所再発症例 8 例中 6 例に対し, 放射線主体治療（放, 放十化）を行ったが，すべて腫愓の control はできなか った.

手術主体治療（手，放 $\rightarrow$ 手十化）を行った 2 症例は， いずれも治癒し現在まで生存している.

e ) 頸部リンパ節転移症例に対する治療と予後(表17)

N0 症例において初回治療後, 頸部リンパ節転移を きたした症例は 8 例で, 頸部邡清術を施行したものは 6 例（単独 2 例, 術前照射 3 例, 術後照射 1 例) で, 放射 線単独治療は 2 例であった. 前者は 6 例中 4 例が治瘾し 
表 16 局所再発症例に対する治療と予後

\begin{tabular}{|c|c|c|c|c|c|c|}
\hline & & \multirow{2}{*}{ 症例数 } & \multicolumn{2}{|c|}{ 予 } & 後 & \multirow{2}{*}{$\begin{array}{l}\text { 現在生 } \\
\text { 存者数 }\end{array}$} \\
\hline & & & 治 & 撚 & 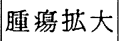 & \\
\hline \multirow{2}{*}{ 故 } & 放 & 1 & & & $1^{*}$ & 0 \\
\hline & 故十化 & 5 & & & 5 & 0 \\
\hline \multirow{2}{*}{ 手 } & 手 & 1 & & 1 & & 1 \\
\hline & 放 $\rightarrow$ 手 + 化 & 1 & & 1 & & 1 \\
\hline & 計 & 8 & & 2 & 6 & 2 \\
\hline
\end{tabular}

表 17 頸部リンパ節転移症例に対する治療と予後

\begin{tabular}{|c|c|c|c|c|}
\hline & \multirow{2}{*}{ 症例数 } & 予 & \multirow{2}{*}{$\frac{\text { 後 }}{\text { 腫瘍拡大 }}$} & \multirow{2}{*}{$\begin{array}{l}\text { 現在生 } \\
\text { 存者数 }\end{array}$} \\
\hline & & 治 㾌 & & \\
\hline 頸部廓清術 & 2 & 2 & & 2 \\
\hline 十術前炤射 & 3 & 1 & 2 & 1 \\
\hline 十術後炤射 & 1 & 1 & & 1 \\
\hline 放射線治療 & 2 & & 2 & 0 \\
\hline 計 & 8 & 4 & 4 & 4 \\
\hline
\end{tabular}

*：他因死 1 例を含む

表 18 死亡原因と生存期間

\begin{tabular}{c|c|c|c|c|c|c|c|c|c}
\hline & 症例数 & $0 \sim 1$ 年 & $1 \sim 2$ 年 & $2 \sim 3$ 年 & $3 \sim 4$ 年 & $4 \sim 5$ 年 & $5 \sim 10$ 年 & 10 年以上 \\
\hline 原発巣拡大 & 11 & 8 & 2 & 1 & - & - & - & - \\
転移单払大 & 8 & 1 & 5 & - & - & 1 & 1 \\
再発巣払大 & 5 & 1 & 3 & - & - & 1 & - & - \\
他 因 死 & 2 & $1 * 1$ & - & - & - & - & - & $1 * 2$ \\
\hline & 26 & 11 & 10 & 1 & - & 2 & 1 & 1 \\
\hline
\end{tabular}

*1: 術後公息死

*2：自殺

たが後者では，いずれも䎐移巣の拡大をきたし死亡し た.

\section{f）死亡原因と生存期間（表18）}

初回治療および再発, 転移に対し治療を行ったが死亡 した患者は26名で, 全症例の44.8\%を占めた。死亡原因 は, 原発巣抎大によるものが11例で最も多く, 以下転移 巣払大によるもの 8 例, 再発栄抎大によるもの 5 例, 他 因死 2 例の順であった。他因死は, 転移巣抎大に対して の頸部遊清術後窒息によるもの,および10年以上経過後 再発し，自殺したものであった。

\section{考察}

顎口腔領域あるいは頭頸部領域の悪性腫瘍, 癌腫にお ける舌癌の頻度について, 現在まで多数の報告がみられ る. 舌癌は口腔外科をはじめ, 耳鼻咽喉科, 放射線科, 外科等の各科や, 各地の癌専門病院・センターの頭頸科 などの施設で取り扱われており，その頻度に関しては， それぞれの特色があり, 単純な比較はできない.しかし 口腔領域悪性腫瘍の中での舌癌の頻度について, 国立が んセンターに怙ける統計2) では口腔悪性腫瘍（上䫇洞，

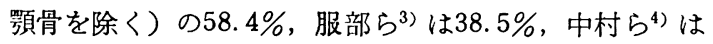
$58 \%$, 北自ら $5^{5)}$ は32.9\%, 山城 ら ${ }^{6}$ ) は36.5\%（上顎洞 癌, 大唾液腺癌を含む）であったと報告しており，いず
れも他部に比べて最も頻度が高かった，われわれも前回 の報告7)で 12年間の口腔悪性腫瘍 186例の統計的観察を 行ったが舌癌は64例 (34.4\%) で最も頻度が高かった. 今回はその5ち一次症例についての治療とその予後の検 討を行った。

\section{1. 臨床統計について}

1）性別执よび年齢別頻度について

性別頻度に関して Flamant $5^{8)}$, Gilbert $ら^{9)}$, 上野 $5^{10)}$ ，松村ら ${ }^{11)}$ の報告では，いずれも男性に多かったと 述べている，われわれの症例に执いても，男性 $63.8 \%$ ， 女性 $36.2 \%$ で男女比は約 $1.8: 1$ であった。

年龄別頻度では, Flamant $5^{8)}$ は50歳台に, 上野ら は50～60歳台に多いと報告しているが，われわれの症例 では 40 歳台に多く $(29.3 \%)$, 他の統計に比べて, やゃ 若年者に好発していた。

2 ) 発生部位について

舌癌の部位別発生頻度について，竹田ら ${ }^{12)}$ は $95.2 \%$ (舌根部を除く), 山本ら ${ }^{13)}$ は $72.7 \%$ が舌縁部で最も多か ったと報告している。われわれの症例でも，舌縁部か5 58 例中38例で65.5\%を占めていた。

3 ）初診時の臨床視診型分類について

初診時の腫瘍の肉眼所見や病態に関し, 桶口 ${ }^{14)}$, 熟 津 $^{(5)}$ ，山下 ${ }^{16)}$ らは，いずれも独自の分類を行っている が, 一般に潰湟型 (内向型) が, 膨隆型 (外向型) に比 
べて多いといわれている，われわれは前述のように，腫 瘤型, 潰瘍型, 白斑型を基本に 7 型に分類したが，この 中でも潰場型が39.7\%を占め最も多かった。

4) 組織型について

舌癌の病理組織診断別頻度について, 国立がんセンタ 一における統計2) では，338例中333例 (98.5\%) が扁平 上皮癌であったと報告している。 また Jeppsson ら 95\%，Gilbert ら`は100\%で，その他の報告でも扁平上 皮癌が压倒的に多かった。 われわれの症例でも扁平上皮 癌が98.3\%を占めていた。

5) TNM 分類について

TNM 分類および TN 分布については種々の報告 があるが，旧 UICC 分類を用いたものが多い，日本 TNM 分類委員会の集計報告 ${ }^{18)}$ に上ればT分類別頻度 ではT 2 が最も多く, 以下 T $1, \mathrm{~T} 3, \mathrm{~T} 4$ の順であり, $\mathrm{N}$ 分類別頻度ではN $0, \mathrm{~N} 1, \mathrm{~N} 2, \mathrm{~N} 3$ の順であった。 また TN 分布では T2N0 が最も多く, 次いで T1N0, T3N0，T2N1，T3N1 の順で多かった。 われわれの症例 においても，T2が最も多く，次いで T 1 の順で, 両者 併せて $79.3 \%$ を占めた。 またN分類ではN 0 が最も多く 48.3\%を占めた。 TN 分布では T1N0，T2N0 の順で多 かった.

\section{6) 病期分類について}

UICC 分類による病期別の頻度について，朔199は， I 期 $17.7 \%$ ，II 期 $12.9 \% ， \mathbb{I I I}$ 期 $25.8 \% ，$ IV 期 $43.5 \%$ であ ったと報告している．われわれの症例も同様であった が， III期および $I V$ 期の進展例がやや多かった。

7）治療法について

舌癌に対する治療は，放射線療法拈よび外科的療法を 主体として，各施設によりそれぞれの特色を生かした方 法により行われている。一般に原発巣に対する治療とし ては，その機能維持といら点から，いわゆる保存的療法 として放射線治療が選択されることが多い．竹田ら ${ }^{12}$ は 1 次症例の $90 \%$ 以上に放射線治療を行っていると報告し ている.われわれの症例に対しても58例中42例に放射線 主体治療が行われている.

舌癌の外科的療法に関し，駕津 ${ }^{20}$ は極めて早期の限局 性腫晹に対し経口的 block resection で十分根治を得ら れ，また $\mathrm{N} 0$ 症例で中等度進展限局性腫場では経口的部 分切除が適応すると述へている．われわれの症例におい て手術主体治療を施行したものは14例 (24.1\%) であり 他施設より比較的多かった。

また化学療法は両者の補助療法として施行して找り, 単独で行ったものは， $\mathbb{N}$ 期の進展例の 1 例だけであっ た.

\section{2. 治療成績について}

1）臨床視診型と予後について

初診時の臨床視診型とその予後に関し，小野 ${ }^{211}$ は，病 型を表在型, 外向型, 内向型の 3 型に分類し, その経過
について, 生存率では表在型が最も高く, 外向型, 内向 型の順で低下したと述べている，また内向型は転移率す 高く予後不良であったとしている．われわれの症例で は，腫瘤・白斑型が治癒率 $90.9 \%$ で最も良好であった。 また腫瘤・潰瘍型では治瘾例は 1 例もなく, 最も予後か 悪かった，潰瘍形成群と，潰瘍非形成群に分けると，前 者は治撚率 $42.4 \%$ (33例中 14例), 後者は $77.3 \%$ (25例 中17例）であり，肉眼的にも内向性の発育を呈している ものは予後不良であった。

2) TNM 分類, 病期分類と予後について

予後の判定に対し, 生存率をもって行らのが直接的て 確実に評価される。しかし生存率集計には種々の方法が あり, 粗生存率, 絶対生存率, 累積生存率, 相対生存率 など，その調査対象の動態により，いずれを用いるかを 考学る必要が生じる，われわれの症例では，すべて予後 調查が行われており，消息不明者むなく，比較的若年者 に多いことや，他因死率も3.4\%で低かったため，粗生 存率を用いて予後を判定した。

舌癌の生存率に関し, 牧野 ${ }^{22}$ は累積生存率で 1 年83.1 $\%, 3$ 年 $51.2 \%, 5$ 年 $43.1 \%$ ，上野ら ${ }^{23}$ はそれぞれ67.5 $\%, 37.8 \%, 31.0 \%$,市川ら ${ }^{24)}$ は粗生存率で59\%， $45 \%$, $41 \%$, 竹田ら ${ }^{12}$ は 3 年 $65.4 \%, 5$ 年 $57.0 \%$ であったと報 告している。われわれの症例では, 粗生存率で 1 年81.0 $\%, 3$ 年 $60.9 \% ， 5$ 年 $55.9 \%$ ，累積生存率でそれぞれ $81.0 \% ， 60.0 \% ， 57.3 \%$ で両者はほとんど 差がなかっ た.

T分類別生存率をみると， Tが増大するにつれて低下 傾向にあり，T 4 ではすべて 1 年以内に死亡していた。

N分類別生存率ではリンパ節転移群（N 1 3）では, 1 年 $73.3 \%, 3$ 年 $43.3 \%, 5$ 年 $37.5 \%$ であったのに対 し，非転移群（N 0) ではそれぞれ 89.3\%，78.3\%， $72.2 \%$ であり，初診時のリンパ節転移の有無が予後に大 きな影響を与えていた。

病期分類別生存率からみると，I期からIV期へ進展す るにしたがい予後が悪くなっているが，II期と期の 1 年, 5 年生存率に逆の成績が羿められた。これは症例数 の少ないこと， III 期の中でも T $1 ， \mathrm{~T} 2$ 症例 (11例) が $\mathrm{T} 3$ 症例（5 例）よりも多かったことなどによると思わ れた。

3）治療法と予後について

舌癌の治療は前述のように放射線照射を主体とした治 療が広く行われて扮り，外科的療法による侵襲は転移を 促進させるという考兄 ${ }^{25)} あ あ る 。$ 竹田ら ${ }^{26)}$ は転移のない 早期の症例では放射線治療も，手術療法も同等の成績を 挙げらることにより，機能保存の意味で前者を優先する と述べている，われわれの症例では，手術主体治療を行 ったものか，58例中14例 (24.1\%) あり，他施設飞比へ 比較的多かったので, 放射線主体治療との比較とい5点 から検討を行った。 
a) $\mathrm{T}$ 分類別治療法と生存年数について

治療法別の予後について, 竹田 ${ }^{12)}$ は 5 年粗生存率 で, 放射線治療 $60.2 \%$ ，切除後放射線治療 $66.6 \%$ ，手術 療法 $25.0 \%$ であったと報告している，われわれの症例で $\mathrm{T}$ 分類別治療法と予後の関係を生存年数によって比較し てみると，T 1 症例では手術主体治療群が放射線主体治 療群に比べ予後が良く, 5 年生存者群の生存率に沶いて も前者 $100 \%$, 後者 $75.0 \%$ であった. T 2 症例では後者 の方が良く, 各症例数に対する 1 年以内死亡率では前者 $33.3 \%$ ，後者 $18.2 \%$ であった。 T $3, \mathrm{~T} 4$ 症例では手術 を施行した症例が少なく比較はできなかった。

b）治療法と予後について

治療法と予後に関し，作田ら 27) は，再発率からみる 之, 放射線単独治療で $28.0 \%$, 放射線・手術併用治療で $50.0 \%$, 放射線・化学療法併用, 放射線・化学療法施行 後手術, 手術単独治療では0\%であったと述べている.

また治療法と転移に関し，奥田ら ${ }^{28)}$ は，放射線照射後 （主として $\mathrm{Ra}$ 針） 7 例中 6 例に，手術例では 7 例中 1 例に転移が生じたと報告しており， $\mathrm{Ra}$ 針の機械的刺激 が転移の原因となる可能性を考虑しなければならないと 述べている，われわれの症例では，初回治療による治瘜 率からみると，手術主体治療 $64.3 \%$ ，放射線主体治療 $23.8 \%$ で，前者の方が優れていた，局所再発率は両者同 率 $(14.3 \%)$ であったが，N0症例に拈ける転移率では 前者 $0 \%$, 後者 $34.8 \%$ であった。このように手術施行症 例の成績が良好であったことは比較的初期癌に手術を行 ったものが多かったことによるものと思われる。

c）予後と生存年数について

治療後局所再発をきたした症例は一般に予後不良とい われており，藤谷ら ${ }^{29)}$ は局所再発群の 5 年粗生存率は 33.3\%であったと報告している。またN 0 症例の初回治 療後の頸部リンパ節転移と予後に関し, 藤谷ら ${ }^{30}$ は 999 例 中55例に転移をきたし，その 5 年実測生存率は $40.0 \%$ で あったと報告している，われわれの症例では局所再発群 の予後は原発巣払大群に次いで不良で, 初回治療後頸部 リンパ節転移群では半数が死亡している.

これらの結果より，初回治療の成績が予後に大きな影 響を与えることが示唆された。

d）局所再発症例に対する治療と予後について

局所再発症例に対する治療に関し，竹田ら $\left.{ }^{12}\right)$ は他医 治療再発例に行ったいわゆる salvage operation (hemiglossectomy, total glossectomy) の 3 年成績は 46\%であ ったと述べている，われわれの症例では再発栄に対し手 術を施行したものは現在まで全例治癒し，放射線治療施 行群では全例死亡した。これは当科では初回治療の経過 観察を頻回に行っており，手術症例は再発を早期に発見 したものが多いためと考えられる。

e ）頸部リンパ節転移症例に対する治療と予後につい $\tau$
$\mathrm{N} 0$ 症例の初回治療後頸部リンパ節転移に対する頸部 廓清術の予後に関し, 藤谷ら ${ }^{30}$ は $53 \%$ に局所再発, 頸部 再発, 遠隔転移による腫瘍死をきたしたと報告してい る、われわれの症例では, 治癒率からみると, 頸部廓清 施行例で $66.7 \%$, 非施行例では0\%であった。 しかし非 施行群では, 手術不能例が多く, 単純な比較は難しいよ らに思われた。

f）死因原因と生存期間について

死亡原因について, 藤谷ら $\left.{ }^{30}\right)$ は, 局所再発死, 頸部転 移巣拡大死，他因死の順で多かったと報告している。 た竹田ら $\left.{ }^{12}\right)$ は 3 年以上経過した症例中, 頸部転移による 死亡例が半数を占めている，われわれの症例では，原発 巣拡大により死亡したものが $42.3 \%$ で最も多かった．原 発巣を control できた症例の中では, 転移巣抎大によ るものが最も多く, 3 年以上生存症例中でも同様の結果 であった．次いで再発巣拡大，他因死の順であったが， これらの結果より, 転移の早期診断, 治療が予後に影響 を与えていると考えられた。

\section{結語}

1) 横浜市立大学医学部口腔外科を訪れた舌癌 1 次症 例58例に対し, 治療と予後の検討を行った. 全例の 5 年 粗生存率は $55.9 \%$ であった。

2）臨床視診型において潰瘍形成群は非形成群に比べ 予後不良であった。

3） T分類別生存率からみると, 腫瘍の払がり程度 （T）が予後に影響を与える重要な因子であった。

$\mathrm{N}$ 分類別生存率からみると, 転移群 (N 1～3) は非 転移群（N0）に比べ明らかに予後不良であった。

4) 治療法別の予後は, 全体的にみると治癒率, 転移 率の点で手術主体治療が放射線主 体治療より優れてい た。また生存年数からみると T 1 症例では, 前者が, T 2 症例では後者が予後良好であった。

5 ）局所再発群の予後は, 原発巣抎大群に次いで不良 であったが，再発巣に対し手術を施行したものは全例治 癒した。

6) N 0 症例の頸部リンパ節転移は半数が死亡してい るが, 転移後の治癒からみると, 頸部廓清施行例は, 非 施行例に比べて予後は良かった。

7 ）死亡原因は原発鉴扗大によるものが最も多いのは 当然であるが，次いで転移巣払大によるものが多く，転 移栄に対する治療も生存率に大きな影響を与えていると 考えられた。

本論文の要旨は, 炤和55年10月, 第25回口腔外科学会 総会（德島）に拈いて報告した。 


\section{引用 文 献}

1) UICC: TNM classification of malignant tumours. International Union Against Cancer, Geneva, Switzerland, 1978.

2) 国立がんセンター頭頸部腫瘍グループ編 : 頭頸 部尰舫図譜。中山畫店, 東京, 1975, 187面.

3）服部浩, 他：腫堵外来に打ける舌癌の統計的 観察。耳喉 41: 6531969 .

4) 中村社網, 他：わが教室10年間の口腔癌の臨床 統計的钼察一試用期間 1974 1977 年の TNM 分類にもとついて一。 日外誌 23：533 1977.

5）北島晴比古，他：当教室に打ける過去10年間の 口腔悪性腫湯の臨床統計的観察。日口外誌 24 : 2611978.

6）山城正宏，他：当科に扣ける過去 4 年間の口腔 悪性腫垍の臨床統計的観察。日口外誌 $26: 327$ 1980.

7) 村瀬博文, 他：口腔覀性腫瘍の臨床病理学的研 究. 第 1 報, 臨床統計的観察。 日口外誌 25 : 721979.

8) Flamant, R., et al.: Cancer of the tongue, a study of 904 cases. Cancer 17: 3771964.

9) Gilbert, E.H., et al.: Carcinoma of the oral tongue and floor of mouth, fifteen years' experience with linear accelerter therapy. Cancer 35: 15171975.

10）上野正，他：口腔癌の治療と予後に関する研 究。第 1 報。只外誌 6: 3961960 .

11）松村智弘，他：舌における扁平上皮癌の検討. I. 臨床所見について。 日外誌 24：269 1978.

12) 竹田千里, 他: 舌がん, 瘦臨 20:301 1974.

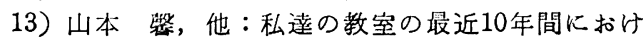
る舌癌の統計的䋩察.耳鼢監床 61：1095 1968.

14）桶口正郎：舌癌の研究。第 2 編。日耳睤 67 :
2921964.

15）热津邦雄：口腔癌の現況とその動向(上)一自験 例を中心に一。粦界展望 47: 3571977.

16）山下久雄, 他：舌癌の放射線治療。癌臨 7 : 1951961.

17) Jeppsson, P.H., et al.: Carcinoma of the tongue. Acta Otolaryng 75: 3141973

18）日本 TNM 分類委員会, 頭頸部小委員会： TNM 分類研究頭頸部関係資科. 国立がん七 ンター頭頸科, 東京, 1980,8 頁.

19) 朔敬：舌扁平上皮癌の予後因子の検討一組 織像ならびに核 DNA 量を中心として一。 日 口外誌 26: 2791980.

20）憵津邦雄：口腔癌の現況とその動向(下)一自鍳 例を中心に。苗界展望 47：511 1977.

21）小野 勇：舌がんの予後に影響を及ぼす因子の 研究一舌可動部がん 221 例の分析より一. 日耳 鼻 80: 1461977.

22) 牧野利男：舌癌の放射線治療の改善に関する研 究。日医放 33：308 1973 .

23）上野 正, 他：生命表補正累積生存率による舌 癌74例の予後成績。口科誌 14:330 1965.

24）市川昭則, 他：教室に打ける舌癌の遠隔成續。 耳鬼 22: 7131976.

25）石川七郎：瘦の転移. 中山書店, 東京, 1972 , 37頁.

26）竹田千里，他：進度別にみた舌癌の治㙩方針の 検討。日癌治 2：265 1967 .

27）作田正義，他：頭頸部扁平上皮癌の再発に関す る研究。日口外誌 26：265 1967.

28）奥田 稔，他：舌癌の転移について。耳院 36: 9071964.

29）藤谷哲造，他：舌癌局所再発症例に関する臨床 的検討。耳喉 48:491976.

30）藤谷哲造，他：舌癌の頸部転移に関する臨床的 検討。耳鬼臨床 70：639 1977. 